\title{
Fantasies of Exposure: Belly Dancing, the Veil, and the Drag of History
}

\author{
JOANNA MANSBRIDGE
}

\section{Introduction}

Is it paternalistic of us in the West to try to liberate women who insist that they're happy as they are? No, I think we're on firm ground. If most Saudi women want to wear a tent, if they don't want to drive, then that's fine. But why not give them the choice? ... If Saudi Arabians choose to kill their economic development and sacrifice international respect by clinging to the 15 th century, if the women prefer to remain second-class citizens, then I suppose that's their choice. But if anyone chooses to behave so foolishly, is it any surprise that outsiders point and jeer? (Nicholas Kristof)

I

n 2011, New Zealand cartoonist Malcolm Evans articulated a pithy truth. His cartoon, "Cruel Culture," shows two women looking at each other, one blond and donning a bikini and sunglasses, the other in a burqa with only her eyes showing. The blonde's thought bubble reads, "Everything covered but her eyes. What a cruel male-dominated culture," while the burqa-clad woman's thought bubble reads, "Nothing covered but her eyes. What a cruel male-dominated culture." A whole history is embedded in this encounter. The simple dichotomy between oppressed and empowered women structuring most media representations of Western and Muslim femininities upholds broader political divisions, in which individual choice, sexual freedom, and visibility are aligned with

The Journal of Popular Culture, Vol. 49, No. 1, 2016

(C) 2016 Wiley Periodicals, Inc. 
Western modernity and democracy, while conformity, modesty, and veiling are aligned with antiquated religious oppression. In both cases, women's bodies are used as sites onto which multiple differences-political, religious, sexual, and cultural-are either imaginatively resolved (belly dancing) or reinforced (the veil). ${ }^{1}$ Saudi women's social agency and public visibility are not merely a matter of choice, but part of complex political, religious, economic, and colonial histories. Kristof s derisive dismissal of them exemplifies the media's failure to think historically and its simplistic deployment of neoliberalized notions of choice. While the stock media image of the veiled Muslim woman threatens neoliberal individualism and its collapsed notions of sexual and political freedom, the image of the belly dancer, as circulated in contemporary Western popular culture, fosters a fantasy of a global (read: universal ${ }^{2}$ ) femininity that is exposed and free. However, as practiced outside of these commodified media contexts, both veiling and belly dancing take on very different, often contradictory meanings that may reveal the histories (of gender, colonialism, modernity, and multiculturalism) that they "drag" with it.

"Drag" - specifically "cultural drag" and "temporal drag"—offers a way of understanding belly dancing as a theatrical practice that is fraught with ambivalences, fantasies, and unfinished histories. The veil, as a socio-religious practice, is not more authentic within this framework; rather, it is the politicized counterpart to the eroticized fantasy that belly dancing performs. One of the contradictions is that many Arab/Muslim women continue to belly dance for employment and pleasure, while Western women have been drawn to belly dancing as a way to feel more sexually empowered. Moreover, the tradition of male belly dancers remains curiously absent in most historical accounts and contemporary practices, while the tradition of belly dancing as a spiritual, feminist practice is often dismissed as trivial or appropriative. The erasure of belly dancing's queer and feminist histories enables the dance to sustain a fantasy of timeless femininity, a fantasy that upholds broader narratives of modernity that depend, in part, on the circulation of the publicly visible, sexualized female body as a sign of freedom and choice within a free market economy. Popular culture representations of belly dancing and media representations of the veil can work together to project polarized images of Western and Muslim femininities, which are understood 
through such binaries as exposed/concealed, timeless/time-bound, universal/restricted, accessible/controlled, free/oppressed. This dualistic image system obscures belly dancing's queer and feminist histories and the veil's use as a symbol of protest and practice of subjectification. In a moment when hostilities surrounding the veil are gaining force and belly dancing is permeating popular culture, it seems especially urgent to historicize these practices, along with the public fantasies that cluster around them, and to mark moments when fantasies of exposure become acts of violence, real and imagined.

Historically, belly dancing and the veil have operated as dialectical counterparts in the West's imagery of Arab and Muslim femininity, playing at the boundary, respectively, between timelessness and backwardness, exposure and concealment, truth and secret, freedom and oppression. In her trenchant study Imagining Arab Womanhood, Amira Jarmakani traces the ways in which Orientalist images of belly dancers, veils, and harems have circulated in twentieth- and twentyfirst century US media and popular culture. Images of sensual belly dancing Arab women and veiled Muslim women, Jarmakani argues, promote a national narrative of expansionism, consumerism, and progress; function as "nostalgic foils for twentieth- and twenty-first century "progress": and mitigate the disorienting "spatiotemporal shifts in the context of modernization and industrial capitalism" (24, 140). She calls the discourse and imagery around veils, belly dancing, and harems "cultural mythologies," since they are naturalized, divorced from their historical and cultural context and invested with the meanings of the appropriating culture. And yet the remaining historical traces make them appear "accurate and authentic representations of Arab womanhood" (4-5). Jarmakani historicizes representations of belly dancing, veils, and harems in relation to growing tensions between the United States and the Middle East. For example, as she points out, "contemporary representations of veiled women cast them as categorically oppressed, metaphorically implying the brutal patriarchal system under which they supposedly live," whereas "[i]mages of transparently veiled women in early-twentieth-century advertisements... eroticize the scene as they suggest the figure to be a coquettish, easily available harem girl" (8). These shifting attitudes toward the veiled Muslim woman tell us that the fantasy of exposing the Muslim woman-making her known to a US gaze - are an 
extension of broader political relations between the United States and the Middle East.

Adding to our understanding of the kinds of fantasies belly dancing promotes in the aftermath of the September 11, 2001 terrorist attacks, Sunaina Maira argues in her incisive analysis of belly dancing in the San Francisco Bay Area that:

belly dancing performances are entangled with the imperial engagements that link the United States and the Middle East and reveal a deeper politics of imperialism, racialization, and feminism in this moment of US empire. The massive appeal of belly dancing and its growing resonance with white American women since 2001 needs to be situated in relation to contemporary gender and nationalist politics. (318)

She rightly adds, "Belly dance performances detach Orientalized femininity from the bodies of Arab women themselves so that it becomes a form of racial masquerade" (33). With its (mythologized) Middle Eastern origins, belly dancing provides Western women an opportunity to play a different role, adopt an alter ego, and perform a fantasy of embodiment and female community unavailable to them in their commercialized, individualistic Western societies. That is, belly dancing gives women license to imitate an idea of femininity that feels more valued, less burdened by history, politics, and capitalist exploitation. Far from being strictly a US or even Western fascination, belly dancing is popular among thousands of women in Australia, Korea, Japan, Brazil, Argentina, Mexico, India, Mongolia, and China, as well as the countries in the Middle East and Central Asia where it has been traditionally practiced.

While Orientalism is a crucial concept, looking at belly dancing solely through this lens perpetuates stereotypes and binary divisions between East and West and fails to explain the dance's circulation in Latin America, China, or other non-Western countries. Rather, the dance can be seen as a hybrid site that enacts and absorbs individual and collective anxieties and longings. Despite its global circulation, belly dancing replays a remarkably stable fantasy of heteronormative femininity, affirming Said's claim that the (masculine) gaze of Orientalism sees the Middle East as "static, frozen, fixed eternally," incapable of "development, transformation, human movement" (208). 
As Donnalee Dox writes, "The Orientalist fantasy of secluded, sensual women that... marked the East's alterity to European culture in the $19^{\text {th }}$ century remains a foundation of belly dancing's appeal to Western practitioners and audiences today" (53). It is as if this stable fantasy of Middle Eastern women allows imaginative control over Islamic cultures that have become increasingly misunderstood and threatening to Western hegemony. However, belly dancing performs an idea of timeless gender and sexuality to which many Western women are deeply attached. With poststructuralism radically destabilizing gender and sexuality, and capitalism relentlessly commodifying them, belly dancing offers women imaginative control over their bodies and sexualities, giving them access to an experience of gender they find both fascinating and reassuring.

Seeing belly dancing as a form of drag reframes it as a performance of identification, imitation, and longing, wherein fantasy assumes material form and political implications. As a critical lens, cultural drag loosens connotations of authenticity and timelessness associated with belly dancing, emphasizing instead its theatricality, ambivalence, and affective investment in a cross-cultural fantasy of gender identity. Although belly dancers do not perform with the ironic, knowing wink often deployed by gay male drag-the wink that gestures toward the artificiality and duplicity of the performancereading belly dancing as drag complicates claims to cultural authenticity and foregrounds gender and culture as mimetic performances that play out the remainders of intersecting histories - of modernization and colonialism - which are also histories of heterosexualization. Butler defines drag: "At its best," she writes, "drag is a site of a certain ambivalence, one that reflects the more general situation of being implicated in regimes of power by which one is constituted and, hence, of being implicated in the very regimes of power that one opposes" (Bodies that Matter 384). Precisely this ambivalence can be read into Western belly dancing performances, which oscillate between complicity and resistance, fascination and longing, essentialism and performativity. Maira rightly explains, "the performance of belly dance by American women represents not so much their ambivalence about Middle Eastern culture, but their ambivalence about their own culture-its individualism, materialism, or restrictive body image ideals" (334). Western women are drawn to belly 
dancing because it gives them access to a relationship with their bodies and their communities that they have lost or been denied.

Thus, belly dancing also implies an identification with and a desire to learn something from Middle Eastern femininity, which is so persistently and reductively cast as the Western femininity's Other. More precisely, belly dancing suggests a desire to know what Western and Arab/Muslim femininities mean in relation to each other. As Butler writes, "the understanding of identification as enacted fantasy or incorporation" makes clear that "coherence is desired, wished for, idealized, and that this idealization is an effect of a corporeal signification" (Gender Trouble 185). Belly dancing idealizes a mythic Middle Eastern femininity, which is understood as sensual without being degraded and objectified, and this idealization reveals a desire for coherent subjectivity among Western women living in a cultural context saturated with hypersexualized images of female bodies. Butler states: "In imitating gender, drag implicitly reveals the imitative structure of gender itself-as well as its contingency" (Gender Trouble 187). Likewise, in imitating a culture-a culture imaginatively projected as a counterimage of Western modernitybelly dancing reveals the imitative, contingent, and historical structure of cultural identity. Western belly dancers long to inhabit a body that is valued, and yet also a body coded as distant, timeless, universal - free from the constraints of culture and history. Part of belly dancing's ambivalence lies in the desire to have it both ways: to grasp identity as something stable and knowable, but also to play with identity as a malleable and spontaneous performance.

Belly dancing might also be read as performing a particular relationship with time and history captured by Elizabeth Freeman's concept of "temporal drag." Temporal drag describes a movement of time that does not advance linearly, but instead pushes forward and pulls back like a wave, leaving debris in its wake. Freeman argues that the formation of subjectivity is a matter of time and timing, of assimilating or "binding" our bodies to a culture's norms of time allocation, which revolve around heteronormative familial structures and an appropriate distribution between work and leisure (what she calls "chrononormativity"). By inhabiting these normative tempos, our flesh is made legible, shaped into socially acceptable forms of embodiment (4). Temporal drag, Freeman explains, must be understood on the level of "collective political fantasy," rather than 
individual psychology, which is then "exteriorized as a mode of bodily adornment or even habitus" (65). Historical time shapes our bodies in similar ways. How does belly dancing produce a form of feminine embodiment that reads as timeless, universal? Staging a stylized, mythic feminine sensuality, belly dancing enacts a longing for a femininity uncomplicated by legacies of imperialism, consumerism, and feminism, even as it "drags" these histories along with it. In this way, the dance performs a fantasmic scene of the unfinished, disavowed histories of Western modernity.

\section{Belly Dancing and the Drag of History}

"How does Orientalism transmit or reproduce itself from one epoch to another?" Said asks (15). One way is through the bodies, affects, fantasies that keep history alive. As an embodied performance steeped in Orientalist ideas about the Middle East, belly dancing offers a rich example of the way affects and fantasies get translated into history. "Belly dancing" is itself a Western term, coined by American musician and entrepreneur Sol Bloom after seeing Fahreda Mazar Spyropoulos and Fatima Djemille (both of whom were known by the stage name "Little Egypt") perform danse du ventre at the 1893 Chicago World's Fair. Since Fatima Djemille was captured in an early silent film, Fatima (dir. James H. White, 1896), the image of the exotic belly dancer has circulated in Western popular culture as a seductive spectacle of cultural and sexual difference. ${ }^{3}$ Early twentieth century female burlesque performers took up the dance, which dovetailed with the Salome craze that swept New York in 1907 and became a stock striptease routine. This marks the beginning of the West's enduring fascination with these dances, or so the story goes, and since then belly dancing has been practiced continually in Western countries, with ebbs and flows in popularity.

Belly dancing has also circulated through patterns of immigration in the nineteenth and twentieth centuries. As Syrians, Lebanese, Turks, Greeks, Egyptians, and other people from the Middle East immigrated to North and South America, the dance began to be performed and adapted by immigrants in their new countries (Bureš 87-88). Dance scholars Anthony Shay and Barbara Sellers-Young explain that belly dancing is a genre "best conceptualized as a 
complex of movement practices that originated in a vast region extending from the Atlantic Ocean in North Africa and the Balkans in the west to the eastern areas of China, Central Asia, and the western portions of the Indian subcontinent in the east." These dances, performed traditionally by both men and women, are "characterized by improvised articulations of the torso, hands, arms, and head" (14). Raqs Sharqi, or Egyptian cabaret-style, is the most commonly adapted form in the West, along with Turkish, or Oriental-style. More contemporary forms, developed mainly in the United States, are called Tribal and Tribal Fusion.

In the 1960s, as the Women's Liberation Movement was getting off the ground and the gender norms and sexual mores of the 1950s were beginning to loosen, belly dancing was taken up in the United States as leisure activity among middle-class women. Belly dance continued to circulate in this period through old Hollywood films, instructional albums made by dancers like Özel Türbaş, ${ }^{4}$ and through classes taught by former performers. The dance provided women with a fantasy femininity that transcended time and place, encapsulating many Western middle-class women's dream of a sensual body liberated from patriarchy and domesticity, careers and car pools, sexualized images and sexual competition. Barbara SellersYoung explains that during this period belly dancing was also approached as a vehicle for feminists to reclaim their bodies from a history of patriarchal oppression (141). Since the 1960s, belly dancing has grown in popularity among middle-class women around the world. In a recent study, sociologist Angela M. Moe interviewed and observed belly dancers in the United States, identifying four feminist aims of the dance: "healing, sisterhood, spirituality, and empowerment" (3; see also Tiggeman et al.). Her research began with her own experience in belly dancing classes, and she reflects on her initial ambivalence toward the dance, writing, "I was immediately struck with an apparent contradiction: If this dance was a mechanism for women's oppression, why did it feel so good?" (7). Moe and other American women use belly dancing to help define the boundary between empowered and objectified sexuality, an enduring sticking point in feminist discourse.

As a primarily female-centered practice, belly dancing today is a worldwide industry, with classes, competitions, conventions, university clubs, and associations in cities around the world. Three claims 
are articulated again and again by contemporary belly dancers: That belly dancing is an art; that it is authentic; and that it is empowering. Designating the dance as art distances it from more explicitly sexual performances, such as stripping. Authenticity-often located in the historically and culturally distant, the ancient or the foreign-is itself a highly manufactured concept that designates, somewhat paradoxically, what has not yet been sullied by the processes of commercialization. Younger dancers, however, tend to emphasize the modern twist they give to belly dancing. As a concept associated with the Western principle of progress, modern codes these performances as liberating and liberated, free from tradition and the vexed history in which the dance is enmeshed. Finally, belly dancing is considered an empowering practice. Rosalind Gill crucially problematizes this overused term, empowerment, pointing out that, in our postfeminist neoliberal media environment, notions like choice, agency, and empowerment have "become commodified - used to sell everything from washing powder to cosmetic surgery." Emptied of its meaning and specificity, "sexual empowerment," she argues, has "become one of the tropes of sexualized culture: everywhere we are confronted by images of empowered female sexuality" (743). "Empowerment" has "itself become a normatively demanded feature of young women's sexual subjectivity, such that they are called on routinely to perform confident, knowing heterosexiness" (737). Belly dancing fosters the feelings of empowerment and sexual confidence necessary to a normative heterosexiness - the "new normal" for young women living in a sexualized culture. Having successfully internalized the processes of objectification, women have learned not only to self-objectify, but also to see this self-objectification as a form of empowerment because done by choice.

The development of belly dancing has not been one-directional, however, nor has the dance been entirely divorced from meaningful traditions and values. R.F. Al-Rawi points out that after belly dancing became popular in North America and Europe in the late nineteenth and early twentieth centuries, "Arab dancers began to incorporate Western dancing in their performances." She explains, "The dancing that used to be performed in a highly concentrated, nearly meditative and inward state... now took a more extravagant and extroverted turn." Broader movements, frenetic twirls, and seductive costumes "combined with the Western image of the Oriental" to 
produce the enduring images we associate with belly dancing. With its "mythologized qualities of sensuality and traditionalism," Al-Rawi argues, belly dancing appealed to "an early-twentieth-century urban population inundated with the technological developments and mechanization of daily life in the early industrial era." Al-Rawi sympathizes with second wave feminist's attraction to belly dancing later in the century, who were drawn to its more traditional inward, meditative mode, although critiques their "apolitical standpoint" and "refusal to take into account the individual's involvement in history." For Al-Rawi, belly dancing becomes a libratory, healing, and spiritual practice when it is situated in the dancer's specific cultural and historical context, whatever that may be. Only in its connection to the conditions of a particular time, place, and performer does the dance become "more than just a dance," but a practice that "refines energy and consciousness"; lends "meaning and depth," "peace," "sensuality and inner freedom" to women's life experience; and provides an "opportunity to express many different selves" (Al-Rawi). In contrast to the stable, timeless femininity that many Western belly dancing performances foster, the dance, if practiced with a historical and cultural consciousness, provides access to multiple identities.

A largely ignored part of belly dancing's history is the popularity of male belly dancers throughout the Middle East and Ottoman Empire. While historically, there were both male and female (çengi) belly dancers in the Ottoman Empire, the cross-dressing boy belly dancer (köģek, zenne, or rakkas) emerged in the nineteenth century when, as Judith Lynne Hanna explains, it was deemed improper for a woman to perform publicly. ${ }^{5}$ Hanna notes that "the Turkish capital in 1805 had about six hundred boys" dancing in taverns (meybanes), and since Turks considered the dance profession degrading, "most of the boys were Greek, Armenian, or Jewish" (57). Köçeks dressed in feminine costumes and toured around the Empire, which, in 1806, spanned modern day Greece, Turkey, Egypt, Tunisia, Syria, Palestine, Serbia, and Romania. While older males also toured and danced in taverns, it was the young köçeks who performed in the palace and participated in the culture of pederasty practiced there (57). Young male dancers continue to perform today in the rural communities of Turkey, as well as in Morocco and parts of the Middle East (57); however, the formation of a modern, "Westernized" Turkish Republic in 1923, under the powerful leadership of Mustafa Kemal Atatürk, 
meant such practices were largely eradicated, along with sexual, ethnic, and religious differences of the köçeks and the audiences who watched them. Meanwhile, today, contemporary Turkish belly dancers, such as Didem Kinali, cater to a fantasy of modern heteronormative femininity. Without lapsing into Orientalist depictions of a feminized Middle East, ${ }^{6}$ belly dancing - so bound as it is to notions of universal, timeless femininity-reveals the historic role that the heteronormativity and the public visibility of the female body plays in narratives of modernity.

Not only belly dancing boys but also covered women were obstacles to Atatürk's idea of a modern Turkish Republic. In 1925, he instituted a ban on religious attire (the face veil, headscarf, turban, and fez), and women wearing headscarves were prohibited from attending universities and working in the public sector as teachers, lawyers, doctors, and public servants ("Turkey: Situation of Women who Wear Headscarves"). ${ }^{7}$ Turkey's modernization meant adopting "homosexual" and "heterosexual" as the defining categories of sexual difference and legislating the public visibility of Turkish women. However, amid the recent political and religious polarization in Turkey and after the country's ruling Justice and Development Party (Adalet ve Kalkinma Partisi, AKP) removed the ban on religious clothing on February 9, 2008, there has been a marked increase in veiling practices throughout Turkey.

Belly dancing does not signify timelessness and universality in the Middle East, but rather bears the historical traces of colonialism that have imbued the dance with connotations of Western imperialism and sexual immorality (Shay and Sellers-Young 16-17). In conservative parts of the Middle East today, belly dancing is held in strong disrepute. Professional belly dancers are thought to be committing haram (a forbidden or sinful act) and routinely face prejudice, except while on stage where they are a source of pleasure for heterosexual male spectators. And as extremism spreads throughout the Middle East, the dance has been increasingly censored; it is outlawed in Iran and Afghanistan, for example, and in Egypt, floor work and exposed midriffs have been banned. In September 2014, a belly dancing reality show was pulled off the air by the government after just one episode ("Egypt's First Reality Show Pulled Off Air"). And yet belly dancers continue to perform in tourist locations in Egypt, such as in hotels, on Nile boat cruises, and in restaurants, catering to a traveling 
Western gaze that sees the belly dancer as an authentic expression of a Middle Eastern cultural tradition. Belly dancers also perform for a local male audience in cabarets, who see them as a source of entertainment. These dancers who perform for tourists and locals alike inevitably participate in the dance's vexed history. Belly dancing performs a half a century of ambivalence surrounding modern sexuality, and women's bodies, whether concealed or exposed, have been the primary sites onto which sexual anxieties have been projected. As cultural and temporal drag - a theatrical performance and movement of historybelly dancing puts into play a collective political fantasy, in which the West wishes to expose the Middle East, while the Middle East protects itself from the political imperialism and moral debauchery of the West.

Turkey productively complicates binaries like East/West, homosexual/heterosexual. In the last several years, the köçek or zenne has made a comeback in Istanbul amid a cultural moment in which global queer politics have converged with a nostalgic return to the country's Ottoman past, encouraged by the AKP government. While drag queens and transvestites have a firm place in Istanbul's cultural scene, the zenne is specific to Turkey's history. As Tara Isabella Burton reports, the revival of zenne dancers has also been spurred by the popularity of Mehmet Binay and M. Caner Alper's film Zenne Dancer, a fictionalized account of the 2007 "honor killing" of belly dancer Ahmet Yildiz, believed to have been carried out by his father after finding out his son was having a same-sex affair with a German photo journalist. Istanbul zenne dancer Segah admits it is difficult to be openly gay outside of the country's largest and most liberal city, although he claims, "When I dance, I create a kind of gender confusion. I am a man - with a beard! - but I'm dancing just like a woman [would]. And that really shocks people. They're shocked into enjoying it" (qtd. in Burton). Dancing at the intersection of Western and Islamic cultures, Segah shocks spectators with a form of cultural and temporal drag that takes up Ottoman history to fashion a contemporary performance of gender confusion. Valerie Traub poses a question that this example raises: "How does the pervasive association of sexual identity with modernity and the West affect the utility of lesbian, gay, and queer discourses for Islamic cultures, past and present?” (2-3). 


\section{Belly Dancing in Contemporary Popular Culture: Performing Sexual Democracy}

Belly dancing takes on different meanings in different contexts, and it can both reinforce and resist the sexualization of culture and the sexualization of concepts like democracy and freedom. In twenty-firstcentury Western popular culture, belly dancing plays out a collective fantasy of cross-cultural relations, in which religious and ethnic differences are displaced by a myth of timeless, global femininity that the dance promotes. In this context, the sensual Middle Eastern woman signifies a kind of universal feminine, while the veiled Muslim woman of the Western imagination operates as the sexual and political Other of this fantasy. Jonathon Brandeis's documentary American Bellydancer: The Pursuit of Life, Liberty, and Dance encapsulates the ways in which this dance has been mobilized in twenty-first-century popular culture as a form of cultural knowledge. The film tracks Miles Copeland, founder of IRS Records and former manager of The Police and Sting, as he tries to put together a touring belly dancing show featuring prominent American belly dancers. His stated goal is to bring belly dancing deeper into American culture, thus fostering greater understanding between the United States and the Middle East. However, as the subtitle suggests, the pursuit of the film is inextricably tied to an American ideology of freedom and democracy, as mapped onto and enacted by the bodies of American belly dancers.

Sadie and Kaya, semifinalists on season ten of "America's Got Talent," and their popular veil dance offer an explicit example of Western individualism masquerading as a mythologized Middle East. Sadie and Kaya perform a heteronormative, body-focused femininity that is aligned with both patriotism and the American Dream. Here, the exposed Western female body signifies (and sexualizes) the Western concepts of freedom and democracy. Sadie and Kaya relish their real bodies and real dreams before the affectively charged backdrop of a waving American flag, as the applauding audience and appreciative judges affirm their performance. It is the dream of opportunity and stardom reimagined in the most evident avenue available to women — through their sexualized bodies. Sadie's belly dancing performances have even gone viral, garnering upward of twenty-seven million views on YouTube. Born in Sheboygan, Wisconsin, Sadie Marquardt travels 
to São Paulo, Mexico City, London, and New York City to perform and teach belly dancing, styling herself as a fusion of orientalist fantasy and global pop culture sensation. The biography page of Sadie's Web site features her almond-shaped green eyes peering through a veil that covers the rest of her face and hair. On either side of this visage are smaller images of her, unveiled and posing seductively in a gold belly dancing costume ("Sadie's Biography"). This particular fantasy of exposure can be read as the unconscious counterpart of the ubiquitous images of veiled Muslim women in the Western media. Sadie's drag symbolically exposes the veiled Muslim woman, while promoting a global femininity paradoxically coded as both timeless and American.

On the British reality television show franchise "Got Talent," belly dancers are common, illustrating the ways in which the imperialist traces of the dance have been translated via the global circulation of Western popular culture. Produced by Simon Cowell, "Got Talent" is cited in the 2014 Guinness World Records as the "Most Successful Reality TV Format" of all time ("Simon Cowell's 'Got Talent"). With over fifty-eight versions, the reality show's worldwide reach is expansive and its brand recognition extremely high. Several belly dancers have appeared on Britain's "Got Talent," including a seventyone-year-old belly dancer named Jan Price; belly dancer Farah Cicekdag made it to the semi-finals of the 2010 season of "Australia's Got Talent"; and belly dancer Alla Kushnir was the winner of the 2011 season of "Ukraine's Got Talent." Indeed, belly dancers have appeared on the British, American, Australian, Korean, Indian, the Ukrainian, Vietnam, China, and the Arab world versions of "Got Talent." The culturally diverse examples of belly dancing's appeal to both performers and audiences, and the commodified image system it circulates within, mobilizes fantasies of femininity and female sexuality to displace and resolve deep cultural differences. Meanwhile, in cities like Dubai and Abu Dhabi, petro-sheikhs pack Western-style strip clubs to watch nude female dancers. In both cases, the exposed female body, whether the belly dancing reality star or the stripper, acts as a reassuring symbol, a short hand way for a culture or nation to show that it is on side with modernity and a free market.

Perhaps the most conspicuous example of belly dancing's global popularity can be seen in Columbian-born singer, songwriter, and choreographer Shakira's trademark belly dancing routine. Shakira's 
self-exoticization resonates with a younger audience that envisions themselves as cosmopolitan consumers, her blond-haired Latina image operating as an ideal canvas on which to project fantasies of a global femininity. With her Columbian nationality and her status as an American pop culture icon, Shakira embodies a kind of globalized femininity. During her 2007 concert in Dubai, for example, she prefaced her signature concert performance of "Ojos Asi"/“Eyes Like Those" with a veil dance that plays with the porous boundaries between visibility and invisibility, as well as between the borders of the cultures she references. The song's recognizably Middle Eastern influences incorporate Arabic chants and use a Phrygian dominant scale. Shakira sings part of the song in Arabic and has recorded Spanish and English versions. Significantly, the lyrics of "Eyes Like Those" reinforce sight - visibility and the gaze - as legitimizing force of the song's female persona, who searches the globe from "Bahrain... to Beirut" for a gaze that will affirm her as the desired object. The abstracted, desiring gaze for which the woman fruitlessly seeks to find a comparable replacement in her global travels can be read as the hegemonic Western gaze, which affirms and defines a globalized femininity that is visible, heteronormative, sexually available, and "free."

The veil registers symbolically in Shakira's performance as a mobile and permeable boundary that enacts an eroticized movement between exposure and concealment and, more politically, between the hypervisibility of the Western female body and the veiled Muslim female body. As Dox succinctly puts it, "If the idea of women's veiling in daily public life is perceived as oppressive, then shedding a costume veil becomes an act of liberation automatically... associated with an industrial, secular, progressive West" (62). Sadie, Kaya and Shakira all use the guise of a mythic Middle Eastern femininity to promote images of (sexual and political) freedom within a Westerndefined global democracy. Belly dancing thus performs in these contexts a desire to know - to expose and make public - what Muslim women's bodies and sexuality mean. Performing in the mythic guise of the temporally and culturally distant belly dancer, rather than through the more familiar image of the stripper, Western belly dancers rehearse an act of cultural supremacy that says something like, "Look at me, looking like you. And yet I'm free and you are imprisoned." 
While belly dancing can promote the idea of a global femininity and sexual democracy, it can also work as a performance of cultural assimilation. In September 2011 on her popular daytime talk show, Ellen Degeneres received a belly dancing lesson from Rosalba. Perhaps the most obvious example of belly dancing as cultural drag, this segment is most striking for the way Degeneres's homonormativity displaces and absorbs cultural difference. Her unthreatening sexual difference works to make the cultural difference signified by the dance unthreatening, and her child-like comic persona transforms the dance's sexual undertones into playful overtones. Los Angeles-based belly dancer Rosalba "entered the world of Middle Eastern dance with a background in Flamenco, Afro-Cuban, Brazilian, and modern dance," as it says on her Web site ("Biography"). Rosalba's appearance on Ellen is a study in contrasts, as the hyperfeminine, exoticized Rosalba teaches the lesbian comedian how to isolate and twist her hips. With a bejeweled bra and gauzy skirt held together by a nude body stocking stretched overtop her typically boyish-butch outfit, Degeneres accentuates her subtly queer sexuality, at the same time as her incongruous appearance mocks the claims to authenticity and timelessness made by so many belly dancers. Ultimately, however, Degeneres's parodic performance does not queer belly dancing, but rather further normalizes her own sexuality and illustrates the way the dance "shores up a multiculturalist or liberal notion of US culture that can consume elements of other cultures" (Maira 334). Ellen's belly dancing performance is a form of cultural drag that mobilizes her homonormativity, whiteness, and unthreatening child-like quality to promote an image of harmonious American multiculturalism.

\section{The Veil in History, Media, and Popular Culture}

"It's like they don't want [women] to have a voice" (King), says Samantha to her friends as they watch two Muslim women eating lunch on the patio of a 5-star hotel in Abu Dhabi in Michael Patrick King's Sex and the City 2. Leaving New York to escape the depressed and depressing economic environment, Carrie, Samantha, Miranda, and Charlotte travel to the wealthy, exoticized Middle East. What follows thereafter is textbook Orientalism. This scene cited above ends with a glimmer of recognition from Carrie, who somehow sees 
beyond the veil of the younger Muslim woman and knows that, despite her covering, the two women are, at heart, the same. This message is reinforced later in the film when the four sexually savvy Manhattanites come face to face with five women wearing burqas. As the Muslim women strip off their coverings to reveal haute couture clothing and flashy jewelry, Carrie exclaims, "Louis Vuitton!" in a tone that can only be described as gleeful relief. (They are just like us!) And her voiceover reduces what is actually a rarely depicted cross-cultural encounter to an exhibition of hyperconsumerism: "There... halfway across the world, under a hundred of years of tradition, was this year's Spring collection" (King). The Middle Eastern women's burqas mask their likeness to the Western women, and it is only after they expose themselves that they can be seen as properly modern, like Carrie and her friends, who operate as the norm against which properly modern femininity is judged. The Muslim women in this scene, and the movie as a whole, simply reflect and reinforce Carrie, Samantha, Miranda, and Charlotte's universal femininity, as defined by the three key characteristics: consumerism, sexual freedom, and heteronormativity. In short, the veil, here, threatens the hegemony of white, heterosexual, US femininity.

As a socio-religious practice and symbolic object, the veil is a complex, contradictory sign at the center of heated debates surrounding the limits of religious freedoms within multicultural societies. As Homa Hoodfar explains, veiling is pre-Islamic. When practiced in connection with seclusion in Greco-Roman and pre-Islamic Iranian and Byzantine empires, veiling was a sign of socioeconomic status. In an Islamic context, veiling practices are culturally specific, and, like belly dancing, intersect with a history of colonial expansion. ${ }^{8}$ As a cultural practice and state of Islamic dress (muhegabba), the veil symbolizes modesty and religious devotion. And although "veiling is nowhere specifically recommended or even discussed in the Qur'an" (Hoodfar 6), as Susie Hawkins notes, "With a few exceptions, most women in Muslim countries are required to wear some form of Islamic dress." She adds, "In some countries, donning the bijab is considered to be the sixth pillar of wisdom-especially in societies that observe Shari'a law" (Hawkins 95, 97). Within an orthodox Islamic context, the veiled Muslim woman metonymically protects the sacredness of Islam, and "Islamists tend to see the role of women as divinely prescribed in Islamic family law" (Islamic Family Law 90). 
In practice, the veil protects a Muslim woman's body from the male gaze and allows freedom of movement in public, giving women access to education and employment.

As far back as the late-nineteenth and early-twentieth-centuries, the veil has been used by the West to construct an image of the uncivilized Islamic world, which worked to legitimize colonial occupations by the self-proclaimed civilized European nations. As Hoodfar points out, by the late-nineteenth-century, "images of Muslim women were used as a major building block to construct the orient's new imagery, an imagery that is intrinsically linked to the hegemony of western imperialism, particularly that of Britain and France" (8). Leila Ahmed adds, "Veiling - to Western eyes, the most visible marker of the differentness and inferiority of Islamic societies-became the symbol... of both the oppression of women... and the backwardness of Islam" (Women and Gender in Islam, 152). Since the nineteenth-century and especially since the Arab-Israeli conflicts began in the 1960s, veiled Muslim women have been reduced in the Western imagination to monolithically oppressed victims of a backward culture, either in need of saving by the liberated West, or subordinated, by ultraconservative Islamic regimes, to a reactionary struggle against Western imperialism.

Since the Gulf War and, even more so, since the September 11 attacks, the veil continues to be manipulated by the media as a monolithic sign of antidemocracy and oppression of Muslim women, an image that justifies the West's neocolonial interventions. Ahmed identifies a "startling" new feature of the post-September 11 public discourse: "The subject of women in Islam, and in particular women's oppression and the emblems of that oppression, such as the veil and the burka, became recurring themes in the broad public conversation in America and elsewhere in the West" (Quiet Revolution, 194). In Women as Weapons of War: Iraq, Sex, and the Media, Kelly Oliver explains, "Reminiscent of the French occupation of Algeria in the 1950s, the US invasion of Afghanistan focused on the plight of Afghan women, whose oppression was seen as epitomized by the veil and the burka" (51). Indeed it was Laura Bush who addressed the nation, making a plea to liberate the women of Afghanistan by using gendered and feminist logic, while the Bush administration and the media made much of the West's success in liberating Afghani "women of cover" (Jarmakani 12). Oliver adds, "Efforts to re-veil 
women in Iraq seem to be a reaction against U.S. occupation wherein westernization becomes associated with women's sexual freedom as evidenced by their dress and the amount of body covered or revealed" (51). What was construed as a humanitarian effort in the 1990s was, after the September 11 attacks, depicted as an unequivocal "war on terror," with the veiled Muslim woman embodying, at once, the enemy threat and the object in need of saving.

The veiled Muslim woman has become a fixation of a Western gaze that sees concealment (of the female body) as a threat to democracy and exposure as a sign of (sexual) freedom. In light of the rising extremism in the Middle East, veiled Muslim women living in Western countries have become an overburdened sign of all that threatens Western democracy and security. They face increasing judgment in the media and increasing infringements on their public freedoms, such as the 2011 law in France forbidding Muslim women to veil their face, Quebec's Charter of Rights, and the establishment of "burqa bans" across the UK and Europe. And the spate of "veil attacks" reported in the United States, France, UK, and Quebec confirms Muslim women's bodies as a conspicuous and volatile site of political, religious, and ideological conflicts. Islamophobia monitoring group Tell MAMA (Measuring Anti-Muslim Attacks) reports that over half of attacks against Muslims happen against women wearing the veil. Over 700 such attacks were reported to Tell MAMA between May 2013 and February 2014 in France, England, the United States, and Quebec (Aziz). For example, a woman was assaulted in a parking lot in Minnesota, another in a suburban community in France, and yet another in a mall in Quebec City. In June 2014, thirty-one-year-old student, Nahid Almanea was stabbed to death on a footpath in Essex, United Kingdom, a murder allegedly instigated by her Islamic dress, which consisted of an abaya and patterned headscarf (Elgot). There is an urgent need for more dialog relating to these violent responses to veiled Muslim women living in Western countries, which might balance the current monocular focus on the oppression of Muslim women under extremist Islamic regimes.

In a curious replay of the 1980s pornography debates, during which there was an alignment of right-wing conservatives and antiporn feminists in their shared antipornography stance, calls for banning the niqab and the burqa are shared by the right and many feminists, who see the veiled Muslim woman as a threat to a free 
(and Christian) Western society. In France, the ban on full-face veiling has been held in place and supported by a public pronouncement of "a certain idea of living together" (Willsher). As Joan Wallach Scott argues in Politics of the Veil, France's laws regulating religious clothing signal the country's failure to integrate its former colonial subjects as full citizens. At the center of the debate, Scott explains, are opposing views of sexuality: In France, as in much of the West, sexual openness stands in for normalcy, emancipation, and individuality, while the sexual modesty implicit in the headscarf and, even more in the niqab, undermines these claims to sexual democracy. Scott rightly points out that France's ban exacerbates religious and ethnic difference by enforcing a cultural homogeneity that is no longer feasible in France. "By refusing to accept and respect the difference of these others," Scott writes, "we turn them into enemies, producing that which we most feared most about them in the first place" (19). The ban in France effectively enforces a historically white Christian hegemony, and in doing so does not allow the veil, or by extension the cultural and religious practices it metonymically invokes, to change French culture. With Britain, Belgium, and Switzerland all now banning face veils, Europe is sending a message of censorship and separatism cloaked as a message of community and secularism. These bans prevent Muslim women from freely moving in public, thus restricting (rather than liberating) them and impeding chances at a diversely integrated community. Furthermore, attempts to ban the burqa and niqab in Austria - even though these are worn by an extremely small proportion of the Muslim women in that country - are a thinly veiled right-wing campaign that resonates with the very sexism that it purports to oppose: "Too beautiful for a veil," is the phrase printed under a photo of a blonde woman in a Facebook post by Austria Freedom Party leader and Member of Parliament Heinz-Christian Strache, who claims to be challenging the "Islamization of Europe" ("Campaign Against Muslim Veils").

The public discourse around the veil has worked to exacerbate tensions and reduce Muslim women to victims of patriarchy and religious extremism. As Ayesha Chaudhry explains, the media focus on veiling has "an adversarial environment by forcing an artificial binary between national citizenship and religious identity" (Chaudhry). Chaudhry succinctly summarizes how these debates divest Muslim women of their agency as subject and citizens: 
Neither forced veiling nor de-veiling actually serves the interests of women, although secularists argue that de-veiling "saves" women from patriarchal oppression, and Islamists argue that veiling "saves" women from an objectifying male gaze that turns them into sex objects. In both arguments, a woman's emancipation or subjugation is measured by the amount her body is covered or uncovered. Both arguments infantilize women, expressing a profound mistrust in their ability to make decisions in their own self-interest. Caught in the middle, Muslim women simply cannot win. (Chaudhry)

As seen from a Western gaze, the veiled Muslim woman's seeming lack of individuality, her explicit demonstration of her commitment to Islam (as both religion and community), and her refusal to offer her body as object and spectacle undermines the foundational principles of Western subjectivity and norms surrounding women's public visibility. Hidden from view, she disrupts the free-flowing circuits of heteronormative desire that are rehearsed in everyday encounters and circulated in global popular culture products. As a social and religious practice, as a symbol of protest, and as a seductive belly dancing prop, the veil plays precisely at the boundary between such discursive constructions as exposure and concealment, public and private, empowered and oppressed, which are used to define Muslim and Western women's bodies - along with the cultures they represent - as diametrical opposites. Both enforced veiling and sexualized hypervisibility reduce women to their bodies - to an object to be looked at or concealed - and in doing so undermine their viability as political subjects and citizens.

Contemporary veiling practices of Muslim women around the world exist in complex negotiation with their societies, their religion, their communities, and their individual choices. Some women wear the veil because of cultural enforcement, others by choice, and yet others as protest. Muslim women have historically mobilized the veil as a sign of protest against patriarchal domination, against European colonialism, and more recently, against US cultural imperialism. For example, the veil became a recognizable symbol during the 1979 Iranian revolution, when many young Iranian women willingly adopted the veil as a sign of protest against the corrupt regime of the Shah. However, under the Islamic Republic, the new freedoms promised to women were reneged, and instead "new rules and regula- 
tions concerning all aspects of women's lives were announced," including mandatory adoption of the veil (chador) (Shirazi 116). In ever growing numbers, Muslim feminists have been wearing the veil as a sign of resistance to a global system defined according to neoliberal Western values of individualism and the free market. Shaista Gohir, chairman of the Muslim Women's Network UK, states that more women have adopted headscarves after the September 11 and July 7, 2005 attacks on the United States and London respectively, in part as a way to make visible their religious and cultural difference from the West and to show pride in their faith and the community ("British Women Fight Racism with the Veil"). Groups like Muslim Women Against FEMEN wear the veil as a sign of protest against Western imperialism and against feminist groups that see veiling as an unequivocal sign of patriarchal domination. Seen in this light, the veil becomes a sign not of oppression, but of agency-not the sexual agency of neoliberal postfeminism, but the agency of mobilized resistance against unjust systems of domination.

The activist group, Muslim Women against FEMEN (MWAF), for example, wear diverse types of veils, while holding written statements that pointedly respond to misunderstandings surrounding the oppressed Muslim woman of the Western imagination and, specifically to the radical feminist group, FEMEN. The photographs posted on the group's Facebook page show Muslim women from around the world, each claiming the veil as a sign of their freedom and dignity. MWAF define themselves as "Muslim women who want to expose FEMEN for the Islamophobes/Imperialists that they are. We are making our voices heard and reclaiming our agency" ("Muslim Women Against FEMEN"). Interestingly, the word "expose" implies an ideological outing of FEMEN, and not a physical unveiling of the female body. Although not self-defined as a feminist group, MWAF can be read as feminist in their praxis in that they advocate recognition of difference and freedom of choice. With written statements such as, "Silence is complicity" and "Nudity DOES NOT liberate me and I DO NOT need saving," MWAF articulate strong counterclaims to FEMEN's condemnation of the veiled Muslim woman as the emblem of patriarchal oppression and veneration of the naked white woman as a symbol of freedom from that oppression ("Muslim Women Against FEMEN"). 
FEMEN is a radical feminist group that formed in 2008 in the Ukraine. FEMEN members use their exposed bodies to communicate their political messages, protesting topless around the world, from the Vatican to Moscow, with militant slogans promoting sexual freedom written on their naked torsos. FEMEN activists use their nakedness to demonstrate against sexual exploitation and political corruption, a startlingly literal tactic in the way it equates public exposure with social equality. The group states their aims clearly on the Web site: "Our Mission is Protest. Our Weapon are [sic] bare breasts!... FEMEN's Goal: complete victory over patriarchy" (femen.org/about). Driving the movement is the belief that the naked female body in protest spells the demise of a patriarchal world system because it demonstrates a woman's "right to her body." Echoing claims made by many belly dancers, who seek through the dance to reclaim a more authentic, liberated form of embodiment, FEMEN's mandate begins with an ahistorical appeal origin: "In the beginning, there was the body, feeling of the woman's body, feeling of joy because it is so light and free. Then there was injustice, so sharp that you could feel it with your body" (femen.org/about). Staging a fantasy of exposure in which naked, white female flesh inscribed with words of protest signifies freedom from patriarchy, FEMEN paradoxically reinforces women's bodies as the site of political conflict, reducing a complex cultural, political, and economic history to a matter of public exposure and individual choice. In contrast to FEMEN's essentialism, MWAF continually assert an awareness of history and emphasize the necessity of recognizing cultural difference. As one young woman's Facebook post succinctly puts it, "My freedom looks different than yours" ("Muslim Women Against FEMEN"). Muslim women who wear the veil as a sign of agency, religious commitment, and indivisibility from their community are performing their identities as changeable, relational, and culturally specific-neither the oppressed Muslim woman of the Western media nor the timeless femininity of the Western belly dancer.

As antagonisms between the Middle East and the West intensify and the tensions surrounding multiculturalism become more pronounced; as Muslim women in the diaspora face hostile scrutiny and women activists in the Middle East are violently suppressed; and as Western feminists align themselves with a neoliberal paternalism and Muslim women rail against the imposition of Western norms of gen- 
der and sexuality, it seems as though, ideologically, the world is divided to the extreme, even as, geographically, we are living in unprecedented proximity to religious, racial, and ethnic differences. Within this scene, belly dancing offers a fantasy of wholeness and universality. Eroticizing and resolving political tensions with the image of a postfeminist, postracial, universal femininity, belly dancing can uphold an idea of global democracy disguised as an exposed, heterosexual female body. In contrast, the Muslim woman's covered body is used by the Western media as a potent symbol of the oppressive patriarchal Islamic regimes, which Western democracy must continue to expose and fight against. As opposing symbols of competing ideologies, women in the West and the Muslim world learn to see each other as antagonists in a global conflict. In an almost perfect replay of Malcolm Evans's cartoon, MWAF and FEMEN confront one another as moral enemies rather than compatriots of the same political system, ${ }^{9}$ in which their bodies are used as an ideological battleground and projected back onto the world as a fantasy of exposure, rather than the drag of history.

\section{Notes}

1. Veil is used broadly here. As both a piece of clothing and as a religious practice in Islam, veiling practices vary across Islamic cultures and countries, as do the terms. The bijab refers to the headscarf and comes from the Arabic word hajaba, or "to hide from view." The niqab is the face veil; abaya is a long cloak worn by Saudi Arabian women; chador is the head and shoulder covering worn by Iranian women; burqa is the full body cloak that covers Muslim women from head to toe. Of these, the niqab and burqa are the most controversial in the West.

2. Following Inderpal Grewal, "global," especially as it is used in twenty-first-century public discourse, is understood as a cognate for "universal" (Grewal 23).

3. Ella Shohat explains the impact of capturing Fatima Djemille in the short film Fatima (Thomas Edison, 1896): "Fatima documents the movements of a dark-haired woman, dressed in 'exotic' costume, with her navel shockingly exposed” (Shohat 49). However, a see-through fence was superimposed onto the celluloid, thus partially covering her bosom and hips. "Fatima's alluring dance," Shohat writes, "was contained through fragmentation and concealment that simultaneously obscured and revealed. The Oriental woman, now in the West, was veiled as it were, but only to tantalize the peeping viewer in the dark" (49-50). This short film is a precursor to the seedy burlesque films produced in the 1950s and 1960s, which feature bump-and-grind burlesquers dancing for a heterosexual male audience in gauzy, bejeweled costumes amid Orientalist mise en scènes.

4. The following is a somewhat anecdotal example: An instructional belly dancing album I found at an antique market in Ankara, Turkey features Turkish-born dancer and actress Özel Türkbas. Remembered in Turkey today as a star of many Turkish films, Türkbas moved to New York City in the 1959 to play the role of "La Orientale" in Franco Zeffirelli's opera Thais. She then began dancing in restaurants and eventually made a series of successful belly 
dancing albums with RCA Records targeted to middle-class American women. With titles such as "How to Make Your Husband a Sultan," which sold over 150,000 copies in the United States and over one million in Turkey. Türkbas's instructional albums affirmed a conventional femininity and her success in both the United States and Turkey suggests the cultural translatability of the fantasy belly dancing performs. Her American counterpart Ann Corio released a successful burlesque album in 1963 called "How to Strip for Your Husband," which came complete with a g-string and jazz score.

5. Although each has a very distinct cultural and theatrical history, female impersonation on stage is a practice found in Chinese, Middle Eastern, and British societies, often revolving around sexual connotations associated with performers and taboos regarding women appearing in public.

6. As Kathryn Babayan and Afsaneh Najmabadi rightly argue, "one cannot exaggerate the significance of historicizing when it comes to studying gender and sexuality in Islamicate cultures," since "Islamic studies and the Islamic world itself continue to be burdened by a scholarly tradition that has all too often situated Islam beyond temporality and geography" (xiii).

7. Erik J. Zücker argues that Atatürk's ban on religious attire was "motivated as much by a desire to claim all visible expressions of authority as a monopoly of the state... as by the wish to secularize society" (187).

8. Nations using Islamic law as their national judicial system enforce religious veiling of women, whereas in countries that use combined or secular legal systems, veiling is not a legally enforced practice. For example, whereas countries like Saudi Arabia and Iraq use Islamic law as the nation's judicial system, which extends to the legislated veiling of Muslim women, countries like Malaysia have a parallel legal system, using both common law and Islamic law. A secular Muslim nation like Turkey, moreover, uses only common law; here, the face veil is illegal, while the headscarf signifies traditionalism within a secular Muslim nation.

9. bell hooks usefully calls this interlocking system "white supremacist-capitalist-patriarchy."

\section{References}

Ahmed, Leila. Women and Gender in Islam. New Haven, CT: Yale UP, 1992. Print.

- A Quiet Revolution: The Veil's Resurgence, from the Middle East to America. New Haven, CT: Yale UP, 2011. Print.

Al-Rawi, R.F. Grandmother's Secrets: The Ancient Rituals and Healing Power of Belly Dancing. Northhampton, MA: Interlink, 2012. Ebook. 11 Aug. 2015.

American Bellydancer. Dir. Jonathan Brandeis. Mondo Melodia Films, 2005. Film.

Aziz, Shaista. "Why Are People So Obsessed with Muslim Women's Wardrobes?" The Guardian. Guardian News and Media Limited, 26 July 2014. Web. 4 Aug. 2014.

Babayan, Kathryn, and Afsaneh Najmabadi. Preface. Islamicate Sexualities: Translations Across Temporal Geographies of Desire. Ed. Kathryn Babayan and Afsaneh Najmabadi. Cambridge, MA: Harvard UP, 2008. vii-xiv. Print. 
"Biography." Rosabla: Professional Bellydancer. Web. 10 Aug. 2014.

"British Women Fight Racism with Veil." OnIslam. OnIslam.net, 23 Aug. 2014. Web. 1 Sept. 2014.

Bureš, Jaroslav. Main Characteristic and Development Trends of Migration in the Arab World. Prague: Institute of International Relations, 2008. Print.

Burton, Tara Isabella. "Inside the World of Istanbul's Male Belly Dancers." Smithsonian. Smithsonian Mag, 9 Dec. 2014. Web. 9 Sept. 2015.

Butler, Judith. Bodies that Matter: On the Discursive Limits of Sex. New York: Routledge, 2011. Print.

- Gender Trouble: Feminism and the Subversion of Identity. New York: Routledge, 2007. Print.

"Campaign against Full-face Muslim Veils Launched in Austria." $R T$. TV-Novosti, 5 July 2014. Web. 31 Aug. 2014.

Chaudhry, Ayesha. "Don't Politicize Women's Bodies." The Globe and Mail. The Globe and Mail, Inc., 5 Aug. 2014. Web. 19 Sept. 2014.

Dox, Donnalee. "Dancing Around Orientalism." The Drama Review 50.4 (2006): 52-71. Web. 4 Apr. 2013.

"Egypt's First Belly Dancing Reality Show Pulled Off the Air." AlTahir News Network. 4 Sept. 2014. Web. 10 Sept. 2014.

Elgot, Jessica. "Student Stabbed To Death On Essex Footpath 'Targeted For Muslim Dress'." Huffington Post UK. AOL (UK) Limited, 19 June 2014. Web. 1 July 2014.

Evans, Malcolm. "Cruel Culture." Evans Cartoons. Malcolm Evans, 6 Jan. 2011. Web. 20 Oct. 2014.

"Eyes Like Yours." Shakira. Metro Lyrics. Web. 30 May 2014.

Fatima's Coochee Coochie Dance. Dir. James White. H. Edison Manufacturing Company, 1896. Film.

FEMEN. femen.org Web. 22 Aug. 2015.

Freeman, Elizabeth. Time Binds: Queer Temporalities, Queer Histories. Durham, NC: Duke UP, 2010. Print.

Gill, Rosalind. "Media, Empowerment and the 'Sexualization of Culture' Debate." Sex Roles 66 (2012): 736-45. Web. 10 Oct. 2015.

Gregory, Michael. "Islamic State Tells Iraqi Women: Wear Full Veil, or Face Harsh Punishment." Reuters. Thomson Reuters, 25 July 2014. Web. 10 Sept. 2014.

Grewal, Inderpal. Transnational America: Feminisms, Diasporas, Neoliberalisms. Durham, NC: Duke UP, 2005. Print.

Hanna, Judith Lynne. Dance, Sex, and Gender: Signs of Identity, Dominance, Defiance, and Desire. Chicago: U of Chicago P, 1988. Print. 
Hawkins, Susie. "The Essence of the Veil: The Veil as Metaphor for Islamic Women." Voices Bebind the Veil: The World of Islam Through the Eyes of Women. Ed. Ergun Mehmet Caner. Grand Rapids, MI: Kregel Publishers, 2013. 93-106. Print.

Hoodfar, Homa. "The Veil in Their Minds and On Our Heads: The Persistence of Colonial Images of Muslim Women." Resources for Feminist Research / Documentation sur la recherche feminist 22.3/4 (1995): 5-18. Print.

Jarmakani, Amria. Imagining Arab Womanbood: The Cultural Mythology of Veils, Harems, and Belly Dancers. London: Palgrave MacMillan, 2008. Print.

Kuruvilla, Carol. "Michigan Man Charged for Attempting to Pull off Muslim Mom's Veil, Cloak.” New York Daily News. NYDailyNews.com, 08 Aug. 2014. Web. 10 Aug. 2014.

Kristof, Nicholas D. "Saudis in Bikinis." New York Times. The New York Times Company, 25 Oct. 2002. Web. 3 Oct. 2014.

Maira, Sunaina. "Belly Dancing: Arab-Face, Orientalist Feminism, and US Empire.” American Quarterly 602 (2008): 317-45. Print.

Moe, Angela M. "Beyond the Belly: An Account of Middle Eastern Dance (aka Belly Dance) as Leisure." Sociology Faculty Publications. Western Michigan University, 2012. 1-32. Web. 14 Sept. 2015.

"Muslim Women Against FEMEN." Facebook. Web. 22 August 2015.

Nelson, Sara C. "Pregnant Woman 'Miscarries After Veil Attack'." Huffington Post UK. AOL (UK) Limited, 19 June 2013. Web. 1 July 2014.

"No-Go Areas in Leicester for Muslim Women Wearing Niqab." Leicester Mercury. Local World, 8 July 2014. Web. 10 Aug. 2014.

Oliver, Kelly. Women as Weapons of War: Iraq, Sex, and the Media. New York: Columbia UP, 2007. Print.

"Sadie's Biography." Sadie Bellydance: International Performing Artist, Instructor \& Choreographer. Web. 15 May 2014.

Said, Edward. Orientalism. New York: Vintage Books, 1978. Print.

Sellers-Young, Barbara. "Raks El Sharqi: Transculturation of a Folk Form." Journal of Popular Culture 26.2 (1992): 141-52. Print.

Sex and the City 2. Dir. Michael Patrick King. New Line Cinema, 2010. DVD.

Shay, Anthony, and Barbara Sellers-Young. "Belly Dance: Orientalism-Exoticism-Self-Exoticism." Dance Research Journal 35 (2003): 13-37. Web. 21 May 2013.

Shirazi, Fagheh. "Islamic Religion and Women's Dress Code.” Undressing Religion: Commitment and Conversion from a Cross-Cultural Perspective. Ed. Linda Arthur. Oxford: Berg, 2000. 113-30. Print. 
Shohat Ella. Taboo Memories, Diasporic Voices. Durham, NC: Duke UP, 2006. Print.

"Simon Cowell's 'Got Talent' Confirmed as World's Most Successful Reality TV Format." 7 Apr. 2014. Web. 16 Oct. 2014.

Tiggemann, Marika, Emily Coutts, and Levina Clark. "Belly Dance as an Embodying Activity?: A Test of the Embodiment Model of Positive Body Image." Sex Roles: A Journal of Research 71.5 (2014). Web. 10 Sept. 2014.

"Turkey: Situation of Women who Wear Headscarves." Research Directorate, Immigration and Refugee Board of Canada, Ottawa. 20 May 2008. Web. 13 Oct. 2015.

Traub, Valerie. "The Past is a Foreign Country? The Times and Places of Islamic Sexuality Studies." Islamicate Sexualities: Translations Across Temporal Geographies of Desire. Ed. Kathryn Babayan and Afsaneh Najmabadi. Cambridge, MA: Harvard UP, 2008. 140. Print.

Wallach, Joan Scott. Politics of the Veil. Princeton, NJ: Princeton UP, 2009. Print.

"Wearing Hijab Helps Body Confidence." British Psychological Association. The British Psychological Society, 12 July 2013. Web. 1 Aug. 2014.

Willsher, Kim. "France's Burqa Ban Upheld by Human Rights Courts." The Guardian. Guardian News and Media Limited, 1 July 2014. Web. 2 July 2014.

Zücker, Erik J. Turkey: A Modern History, 3rd ed. London: I.B. Tauris, 2004. Print.

Joanna Mansbridge is Assistant Professor in the Department of American Culture and Literature at Bilkent University. Her research spans modern and contemporary American theatre, performance studies, film and visual culture, and gender studies. Her monograph, Paula Vogel (University of Michigan Press, 2014), is the first book-length study on the playwright. She is on the international advisory board for the performance studies journal Performance Matters. 